\title{
SPECIES LIST AND CONSERVATION PRIORITY OF BUTTERFLIES (Lepidoptera, Rhopalocera) IN DONG VAN KARST PLATEAU, HA GIANG PROVINCE
}

\author{
Vu Van Lien \\ Vietnam National Museum of Nature, VAST, vulien@ vnmn.vast.vn
}

\begin{abstract}
Study on species and conservation priority of butterflies in Dong Van Karst Plateau, Ha Giang province was carried out in forests of Lung $\mathrm{Cu}$, Pho Bang, Ta Phin and sites near Dong Van town. The habitats are the natural forest on mountain, the secondary forest, the forest edge, shrub and grass from 1,400 to 1,700 m a.s.l. The study was carried out uncontinuously from May to September in 2008, 2010 and 2011. Total 132 species of 5 butterfly families were recorded during studied period. Two species listed in the Red Data Book of Vietnam and CITES are Troides aeacus and Teinopalpus imperialis. There are 33 species with individuals 1-2 (25\% of all species), 44 species with individuals 3-5 (33\% of all species), 14 species with individuals $6-10$ (11\% of all species), and 41 species with individuals more than 10 (31\% of all species). Butterfly species of Dong Van karst plateau consists of $12.6 \%$ of all butterfly species of Vietnam, but the family Papilionidae of Dong Van karst plateau consists of $40 \%$ of all species of the family of Vietnam. The family Papilionidae is very important for conservation of insects. Some species distributed in Vietnam merely found in the studied area are Byasa hedistus, Papilio elwesi, Sasakia funeblis, S. charonda, and Melitaea yuenty. These species are rare and distribute in forests where forests are being declined. So it is needed conservation measures to conserve, especially conserve the natural forests in Dong Van karst plateau, the habitat of these butterflies.
\end{abstract}

Keywords: Conservation, karst plateau, rare species, threatened species.

\section{INTRODUCTION}

Butterflies of Vietnam were studied from the early years of the twentieth century. The first work on butterflies in Vietnam "Indochina Insects" by Dubois and Vitalis (1919) with a list of 611 species [3]. Metaye (1957) [7] listed 454 species of butterflies of Vietnam. Especially since the 1990s, a number of studies on butterflies were carried in National Parks and Nature Reserves of Vietnam (e.g. [9, 14, 16]).

Dong Van karst plateau, a Global Geopark, at an average altitude of 1,400 $\mathrm{m}$ a.s.l., stretches over areas of 4 districts of Quan Ba, Yen Minh, Meo Vac and Dong Van of Ha Giang province. This is one of special limestone areas of Vietnam, contains typical marks on the history of development of the earth's crust. Some small native forests in the area are still relatively intact.

Insect fauna of Ha Giang in general and Dong Van karst plateau in particular have not been studied much. In additional, Dong Van karst plateau is a unique karst Geo-ecology and diversity, some species of insects of Vietnam are merely found here [16]. The work is the result of research on butterfly species and their conservation value in Dong Van karst plateau, Ha Giang province, and to reveal more information about beautiful creatures for the area and Vietnam.

\section{MATERIALS AND METHODS}

More than 5,000 specimens of butterflies were collected in Dong Van karst plateau, Dong Van district, Ha Giang province.

Research was carried out uncontinuously from May to September in 2008, 2010 and 2011 with the total of 60 surveyed days. The day time of survey was from 9.00am to $16.00 \mathrm{pm}$.

The study was conducted in forests of Lung $\mathrm{Cu}$, Pho Bang, Ta Phin and areas near the Dong Van town, from $1,400 \mathrm{~m}$ to $1,700 \mathrm{~m}$ a.s.l. in the Dong Van karst plateau.

Habitats are natural forest, regenerating forest, secondary forest, forest edges, shrub and grassland, and residential areas. 
Butterflies were collected randomly in different habitats by insect nets. Butterflies specimens were dried and put in envelopes, some of them were mounted and kept in boxes. The specimens are deposited at the Vietnam National Museum of Nature. More than 5,000 butterflies collected by local collectors were examined to record and check the presence of the species in the study area. In addition, the presence and relative abundance of butterfly species were also recorded in the surveys to assess the relative abundance of species.

Identification of butterflies is followed by Chou (2004) [1], D’Abrera (1982-1986) [2], Le Cerf (1923) [5], Leech (1891) [6], Monastyrskii \& Devyatkin (2003) [9], Osada et al. (1999) [11], Racheli \& Cotton (20110) [12], Vu (2012) [15].

\section{RESULTS AND DISCCUSSION}

Total of 350 specimens of butterflies are collected during the surveys. There are 132 butterfly species of 5 families (Papilionidae, Pieridae, Nymphalidae, Lycaenidae, and Hesperiidae) recorded in the Dong Van karst plateau (Table). The family Nymphalidae has the most species (59 species, $44.7 \%$ of total species), following by the family Papilionidae (25 species, $18.9 \%$ of total species).

Two species are listed in the Red Data Book of Vietnam, list of CITES and IUCN, are Troides aeacus and Teinopalpus imperialis [8, 10]. Among the species, there are 33 rare species with individuals $1-2$ (25\% total species), 44 uncommon with individuals 3-5 (33\% total species), 14 rather common species with individuals 6-10 (11\% total species), and 41 common species with individuals more than 10 (31\% total species).

Rare typical species with large wingspans are Atrophaneura polyeuctes, A. varuna, Byasa hedistus, Papilio arcturus, P. dialis, P. elwesi, P. machaon, Teinopalpus imperilialis, and Troides aeacus (family Papilionidae); Childrena childreni, Euthalia sahadeva, Helcyra superb, H. subalba, Neurosigma siva,
Sasakia charonda and S. funeblis (family Nymphalidae).

The most common species are Graphium cloanthus, Papilio helenus, P. xuthus (Papilionidae); Hebomoia glaucippe (Pieridae); Junonia iphita, J. orithya, Polygonia c-aureum (Nymphalidae) and Heliophorus brahma (Lycaenidae). These species were checked from local collectors with hundreds individuals of each species.

The number of butterfly species recorded in Dong Van accounted for $13.07 \%$ (132/1010 species) of butterflies of Vietnam. The family Papilionidae of Dong Van accounted for 37.3\% of butterfly species of the family Papilionidae in Vietnam (25/67 species) [14]. There are 10 butterfly species in the Red Data Book of Vietnam; the family Papilionidae of Vietnam has up to 7 species [8].

The family Papilionidae is considered as "representative" for the diversity of butterflies [13]. This family has many rare butterfly species; some species of them are in critical endangered state. They have great size, nice color, high aesthetic value should normally be collected and traded. Most butterfly species in CITES and IUCN list belong to the family Papilionidae [10].

Some species with special concern are as following:

\section{Papilio elwesi Leech, 1889}

Distributed in northern Vietnam and China. In Vietnam, the species is only found in the forests of Dong Van. It is very rare. The status of the species: threatened due to degradation and decline of natural forests and over-hunting. The species can be at risk of threat (VU).

Byasa hedistus (Jordan, 1928)

Distributed in North Vietnam, Burma and western China. In Vietnam, the species is only found in the study area. It is very rare species, distributed in the natural forests. The status of species: threatened due to degradation and decline of natural forests and catching. The species can be at risk of threat (VU). 
Species list and conservation priority of butterflies

Table. Butterfly species list and their abundance in Dong Van karst plateau

\begin{tabular}{|c|c|c|c|c|c|}
\hline No. & Family, species & Abundance & No. & Family, species & Abundance \\
\hline \multicolumn{6}{|c|}{ Family Papilionidae } \\
\hline 1 & Atrophaneura varuna (White) & + & 14 & Papilio arcturus Westwood & ++ \\
\hline 2 & Byasa hedistus (Jordan) & + & 15 & Papilio bianor Cramer & ++ \\
\hline 3 & Byasa polyeuctes (Doubleday & + & 16 & Papilio dialis doddsi Janet & + \\
\hline 4 & Graphium agamemnon (Lin.) & ++ & 17 & Papilio elwesi Leech & + \\
\hline 5 & Graphium antiphates Cramer & ++ & 18 & Papilio helenus Linnaeus & ++++ \\
\hline 6 & $\begin{array}{l}\text { Graphium cloanthus } \\
\text { (Westwood) }\end{array}$ & ++++ & 19 & $\begin{array}{l}\text { Papilio machaon verityi } \\
\text { Fruhstofer }\end{array}$ & + \\
\hline 7 & $\begin{array}{l}\text { Graphium doson (Felder \& } \\
\text { Felder) }\end{array}$ & ++ & 20 & Papilio nephelus Boisduval & ++ \\
\hline 8 & Graphium eurous Leech & ++ & 21 & Papilio paris Linnaeus & ++++ \\
\hline 9 & Graphium sarpedon (Lin.) & ++++ & 22 & Papilio protenor Cramer & ++++ \\
\hline 10 & Graphium xenocles Dou. & ++++ & 23 & Papilio xuthus Linnaeus & ++++ \\
\hline 11 & $\begin{array}{l}\text { Lamproptera curius } \\
\text { (Fabricius) }\end{array}$ & ++ & 24 & $\begin{array}{l}\text { Teinopalpus imperialis } \\
\text { imperatrix de Niceville }\end{array}$ & + \\
\hline 12 & $\begin{array}{l}\text { Lamproptera meges Zinken- } \\
\text { Sommer }\end{array}$ & ++ & 25 & Troides aeacus (Fel. \& Fel.) & + \\
\hline 13 & $\begin{array}{l}\text { Meandrusa sciron } \\
\text { hangiangensis Funahashi }\end{array}$ & ++ & & & \\
\hline \multicolumn{6}{|c|}{ Family Pieridae } \\
\hline 26 & Appias albina (Boisduval) & ++ & 31 & Eurema blanda (Wallace) & ++ \\
\hline 27 & Appias lyncida Cramer & ++ & 32 & $\begin{array}{l}\text { Gonepteryx amintha } \\
\text { Blanchard }\end{array}$ & ++ \\
\hline 28 & Catopsilia pomona Fabricius & +++ & 33 & Hebomoia glaucippe (Lin.) & ++++ \\
\hline 29 & Cepora nerissa Fabricius & ++ & 34 & Prioneris thestylis Doubleday & +++ \\
\hline \multicolumn{6}{|c|}{$\begin{array}{l}\text { Family Nymphalidae } \\
\text { Subfamily Danainae }\end{array}$} \\
\hline 35 & Euploea core (Cramer) & ++ & 38 & Parantica melaneus (Cramer) & ++ \\
\hline 36 & Euploea midamus (Linnaeus) & ++ & 39 & Parantica sita (Kollar) & ++ \\
\hline 37 & Euploea mulciber (Cramer) & +++ & 40 & Tirumala septentrionis (Butler) & ++ \\
\hline \multicolumn{6}{|c|}{ Subfamily Satyrinae } \\
\hline 41 & $\begin{array}{l}\text { Callerebia narasingha } \\
\text { dohertyi (Evans) }\end{array}$ & +++ & 47 & Melanitis leda (Linnaeus) & ++ \\
\hline 42 & Lethe bhairava (Moore) & + & 48 & Melanitis phedima (Cramer) & ++++ \\
\hline 43 & Lethe confusa Aurivillius & +++ & 49 & Mycalesis sp. & + \\
\hline 44 & Lethe kansa (Moore) & + & 50 & Neope pulaha (Moore) & ++++ \\
\hline 45 & Lethe rohria (Fabricius) & + & 51 & Ragadia crisilda de Niceville & + \\
\hline 46 & Lethe sinorix (Hewitson) & + & & & \\
\hline \multicolumn{6}{|c|}{ Subfamily Nymphalinae } \\
\hline 52 & Argyreus hyperbius (Linnaeus) & +++ & 73 & Junonia iphita (Cramer) & ++++ \\
\hline 53 & Ariadne ariadne (Linnaeus) & ++ & 74 & Junonia orithya (Linnaeus) & ++++ \\
\hline 54 & Athyma cama Moore & ++ & 75 & Kaniska canace (Linnaeus) & + \\
\hline 55 & Athyma opalina (Kollar) & ++++ & 76 & Limenitis sulpitia (Cramer) & +++ \\
\hline 56 & Athyma perius (Linnaeus) & ++ & 77 & $\begin{array}{l}\text { Melitaea yuenty yuenty } \\
\text { Oberthur }\end{array}$ & + \\
\hline 57 & Cethosia biblis (Drury) & ++ & 78 & Neptis sankasa (Kollar) & ++++ \\
\hline 58 & Childrena childreni Gray & + & 79 & Neptis sappho (Pallas) & + \\
\hline 59 & Cirrochroa tyche (Felder) & ++ & 80 & Neurosigma siva Cramer & + \\
\hline
\end{tabular}




\begin{tabular}{|c|c|c|c|c|c|}
\hline 60 & Cyrestis thyodamas Boisd & ++ & 81 & Parasarpa dudu (Westwood) & ++++ \\
\hline 61 & $\begin{array}{l}\text { Dichorragia nesimachus } \\
\text { (Doyere) }\end{array}$ & ++++ & 82 & Polygonia c-aureum (Lin.) & ++++ \\
\hline 62 & Dilipa morgiana (Westwood) & ++++ & 83 & Polyura athamas (Drury) & ++ \\
\hline 63 & Euripus nyctelius Doubleday & + & 84 & $\begin{array}{l}\text { Rohana parvata burmana } \\
\text { (Tytler) }\end{array}$ & ++ \\
\hline 64 & Euthalia sahadeva Moore & + & 85 & Sasakia charonda & + \\
\hline 65 & Euthalia sp. & + & 86 & $\begin{array}{l}\text { yunnanensis Fruhstorfer } \\
\text { Sasakia funeblis funeblis } \\
\text { (Leech) }\end{array}$ & + \\
\hline 66 & Helcyra superb superb Leech & + & 87 & Stibochiona nicea (Gray) & ++ \\
\hline 67 & Helcyra subalba (Poujade) & + & 88 & Sumalia darasa Doubleday & ++++ \\
\hline 68 & Hestina assimilis (Linnaeus) & ++++ & 89 & $\begin{array}{l}\text { Symbrenthia hypselis } \\
\text { (Godart) }\end{array}$ & ++++ \\
\hline 69 & Hestina persimilis Westwood & ++++ & 90 & Symbrenthia lilaea Hewitson & ++++ \\
\hline 70 & Hestina nama (Doubleday) & ++++ & 91 & Vanessa indica Herbst & ++++ \\
\hline 71 & Hypolimnas bolina (Lin.) & +++ & 92 & Vargans egista (Cramer) & ++++ \\
\hline 72 & Jumonia almana (Linnaeus) & ++ & 93 & Vindula erota (Fabricius) & ++ \\
\hline \multicolumn{6}{|c|}{$\begin{array}{l}\text { Family Lycaenidae } \\
\text { Subfamily Riodininae }\end{array}$} \\
\hline 94 & Dodona dipoea Hewitson & ++++ & 96 & Zemeros flegyas (Cramer) & ++ \\
\hline 95 & Dodona egeon Westwood & ++++ & & & \\
\hline \multicolumn{6}{|c|}{ Subfamily Lycaeninae } \\
\hline 97 & Ancema sp. & ++++ & 106 & Pratapa icetas (Hewitson) & ++++ \\
\hline 98 & Arhopala bazalus Hewitson & ++ & 107 & Rapala rectivitta (Moore) & ++++ \\
\hline 99 & Arhopala sp. & + & 108 & Rapala sp. & +++ \\
\hline 100 & Curestis bulis (Westwood) & +++ & 109 & Satyrium sp. & ++++ \\
\hline 101 & Deudorix epijarbas (Moore) & + & 110 & Sinthusa chandrana (Moore) & + \\
\hline 102 & Heliophorus brahma Moore & ++++ & 111 & Spindasis lohita (Horsfield) & +++ \\
\hline 103 & Hypolycaena erylus (Godart) & ++ & 112 & $\begin{array}{l}\text { Surendra querceborum } \\
\text { (Moore) }\end{array}$ & ++++ \\
\hline 104 & Ionolyce helicon (C. Felder) & ++++ & 113 & $\begin{array}{l}\text { Tajuria illurgioides de } \\
\text { Niceville }\end{array}$ & +++ \\
\hline 105 & Lampides boeticus (Linnaeus) & ++ & 114 & Tajuria maculata Hewitson & ++++ \\
\hline \multicolumn{6}{|c|}{ Family Hesperiidae } \\
\hline 115 & Ahlbergia chalcides Chou \& Li & ++ & 124 & Hasora danda Evans & +++ \\
\hline 116 & Burara vasutana (Moore) & + & 125 & Hasora vitta (Butler) & + \\
\hline 117 & Capila lineata Chou \& $\mathrm{Gu}$ & ++++ & 126 & $\begin{array}{l}\text { Koruthaialos sidu (Felder \& } \\
\text { Felder) }\end{array}$ & ++ \\
\hline 118 & $\begin{array}{l}\text { Carterocephalus christophi } \\
\text { Grum - Grshimailo }\end{array}$ & ++++ & 127 & Parnara sp. & ++ \\
\hline 119 & $\begin{array}{l}\text { Celaenorrhinus maculosus } \\
\text { (Felder \& Felder) }\end{array}$ & ++++ & 128 & $\begin{array}{l}\text { Polytremis lubricans (Herrich } \\
\text { - Schaffer) }\end{array}$ & ++ \\
\hline 120 & $\begin{array}{l}\text { Choaspes hemixanthus } \\
\text { (Rothschild) }\end{array}$ & + & 129 & Potanthus sp. & ++ \\
\hline 121 & Coladenia dan fabia (Evans) & ++ & 130 & Satarupa gopala Moore & + \\
\hline 122 & Gerosis sp. & ++++ & 131 & Scobura sp. & ++ \\
\hline 123 & Halpe sp. & ++ & 132 & Udapes folus (Cramer) & ++++ \\
\hline
\end{tabular}

Note: Order of species in the families/subfamilies by Alphabet; + 1-2 individuals; ++: 3-5 individuals; +++: 5-10 individuals; ++++: more than 10 individuals. 
Species list and conservation priority of butterflies

Meandrusa sciron hajiangensis Funahashi, 2003

Distribution in Dong Van and may be in some other areas such as Meo Vac, Quan Ba and Yen Minh of $\mathrm{Ha}$ Giang province. New subspecies was discovered in 2003 [4]. The species is uncommon, distributed in high mountain forests. The species might be at risk of threat (LC) due to degradation and decline of natural forests.

Teinopalpus imperialis imperatrix de Niceville, 1899

Distributed in Burma, China, northern Thailand, Laos, and Vietnam. In Vietnam, the species is distributed in the high mountain forests of Lao Cai, Yen Bai, Cao Bang, Ha Giang, Kon Tum.

In the study area the species is distributed in natural forests. The status of species: the species can be at risk of threat (VU) due to the degradation and decline of natural forests and catching. However, the species is distributed in different areas of the mountain forests of Vietnam.

Sasakia charonda yunnanensis Fruhstorfer, 1913

Distributed in northern Vietnam, southern China (Yunnan and Guizhou). In Vietnam, the species is rare and only found in Dong Van. The status of species: Threatened due to degradation and decline of natural forests and over-hunting. The species can be at risk of threat (VU).

Sasakia funeblis funeblis (Leech, 1891)

Distributed in Assam, northern Vietnam, and southern China. In Vietnam, the species is rare and only found in Dong Van. The status of species: threatened due to degradation and decline of natural forests and catching. The species can be at risk of threat (VU).

Melitaea yuenty yuenty Oberthur, 1886

Distributed in northern Vietnam and China. In Vietnam, the species is uncommon and only found in the study area. The species distributes in the natural forests. Status: the species might be at risk (LC) due to degradation and decline of natural forests.

Helcyra superba superba Leech, 1890
Distributed in Vietnam and China. In Vietnam only found in Dong Van. Uncommon species lives in the mountain forest habitats. The species might be at risk (LC) due to degradation and decline of natural forests.

Conservation status assessment: The mountain forests of Dong Van karst plateau is declined and degraded due to logging, taking firewood, agricultural and residential expansion. The area and quality of forests are severely reduced. While there is a number of butterfly species of Vietnam only seen distribution here. So, Dong Van is very important to maintain the existence of these butterfly species, particularly species of large size, pretty morphology, and rare such as Papilio elwesi, Byasa hedistus, Sasakia funeblis, S. charonda, Melitaea yuenty, Teinopalpus imperialis, and Troides aeacus. If natural forests are no longer existed here, the butterflies will be also disappeared and Vietnam will lose these valuable species. The species could be at risk of threat (VU) as they are rare, small distribution range in forests which are being degraded and declined. The species need to be conserved are Papilio elwesi, Byasa hedistus, Sasakia funeblis, S. charonda.

\section{CONCLUSION}

The study recorded 132 species of butterflies in Dong Van karst plateau. Two species recorded in the CITES list are Troides aeacus and Teinopalpus imperialis. Species number of the family Papilionidae is accounted for $37.3 \%$ of their species in Vietnam. In particular, some species of Vietnam is only found here are Byasa hedistus, Papilio elwesi, Sasakia funeblis, $S$. charonda, and Melitaea yuenty. These are very valuable species. They should be conserved prioritily. The remaining forests are declined; these rare butterfly species are at risk of threat. Dong Van karst plateau, a global Geopark, is not only geological values, but also particularly conservation value of these rare butterflies.

\section{REFERENCES}

1. Chou L., 1994. Monographia Rhopalocerum Sinensium. Vol. 1-2. Henan Science and Technology Press, Henan, China, 854 p. 
2. D'Abrera B., 1982-86. Butterflies of the Oriental Region. Volumes 1-3. Hill House, Melbourne, $672 \mathrm{p}$.

3. Dubois E., Vitalis de Salvaza R., 1919. Essai d'un traite d'entomologie indochinoise, Hanoi, 308 p.

4. Funahashi A., 2003. Butterflies of Vietnam part 2, Descriptions of 19 New subspecies of Butterflies from Vietnam. Wallace, 8: 315,4 pls.

5. Le Cerf F.,1923. Descriptions de formes nouvelles de Lepidopteres Rhopaloceres. Bull. Mus. Natn. Hist. Nat., Paris, 29: 360367, 428-429.

6. Leech J. H., 1891. New species of Rhopalocera from Western China. Entomologist, 24: 23-31.

7. Metaye R., 1957. Contribution a l'etude des lepidopteres du Vietnam (Rhopalocera). Khoa-Hoc Dai-Hoc Duong Saigon. Annals of the Faculty of science, University of Saigon, pp. 69-106.

8. Ministry of Science and Technology, Vietnam Academy of Science and Technology, 2007. The Red Data Book of Vietnam, part 1. Animals. Science and Technology Publishing House, Hanoi, pp. 452-470 (in Vietnamese).

9. Monastyrskii A. L., Devyatkin A. L., 2003. A system list of butterflies of Vietnam. Thong Nhat Publishing House, 56 p., 14 pls.

10. New T. R., Collins N. M., 1991. Swallowtail
Butterflies: An action plan for their conservation, IUCN, Gland, Switzerland, 36 p.

11. Osada S., Uemura Y., Uehara J., 1999. An illustrated checklist of the butterflies of Laos P.D.R. Tokyo, Japan, 240 p.

12. Racheli T., Cotton A. M., 2010. Guide to the Butterflies of the Palearctic Region. PAPILIONIDAE part 2. subfamily Papilioninae. Omnes Artes, Milano, $86 \mathrm{p}$.

13. Vane-Wright R. I., 2005. Conserving biodiversity: a structural challenge. A report on insect inventory project in Tropic Asia (ed. Yata). Faculty of Social and Cultural Studies, Kyushu University, Fukuoka, Japan, pp. 27-49.

14. Vu Van Lien, 2010. Diversity of butterflies of Vietnam. Scientific Conference of the $35^{\text {th }}$ anniversary of the Vietnam Academy of Science and Technology (1975-2010). Science and Technology Publishing House, pp. 22-27 (in Vietnamese).

15. Vu Van Lien, 2012. Two butterfly species of rare and precious genus Teinopalpus Hope, 1843 in Vietnam. TAP CHI SINH HOC, 34(3): 323-327 (in Vietnamese, summary in English).

16. Vu Van Lien, Ta Huy Thinh, 2005. The similarity of butterfly species in some areas and an additional list of new record of Vietnam. The National Proceeding on the Ecology and Biological Resources, the first National workshop. Agricultural Publishing House, Ha Noi, pp. 144-149 (in Vietnamese).

\section{THÀNH PHẦN LOÀI VÀ ỦU TIÊN BẢO TỒN CÁC LOÀI BƯớM (Lepidoptera, Rhopalocera) Ở CAO NGUYÊN ĐÁ ĐÔNG VĂN, TỈNH HÀ GIANG}

Vũ Văn Liên

Bảo tàng Thiên nhiên Việt Nam, Viện Hàn lâm KH\&CN Việt Nam

\section{TÓM TÁT}

Nghiên cứu thành phần và ưu tiên bảo tồn của các loài bướm ở Cao nguyên đá Đồng Văn được thực hiện tại các khu rừng ở Đồng Văn. Sinh cảnh nghiên cứu là rừng tự nhiên trên núi, rừng thứ sinh, bìa rừng, cây bụi 
và cỏ, và khu dân cư, độ cao 1400-1700m so với mực nước biển. Điều tra được tiến hành rải rác từ tháng từ tháng 5-9 trong các năm 2008, 2010 và 2011. Tổng số 132 loài bướm đã được ghi nhận. Hai loài có trong Sách Đỏ Việt Nam và danh lục CITES là Troides aeacus và Teinopalpus imperialis. Có 33 loài (1-2 cá thể, chiếm $25 \%$ tổng số loài), 44 loài (3-5 cá thể, chiếm $33 \%$ tổng số loài), 14 loài (6-10 cá thể, chiếm $11 \%$ tổng số loài), 41 loài (hơn 10 cá thể, chiếm $31 \%$ tổng số loài). Số loài bướm ở đây chiếm $13 \%$ tổng số loài bướm Việt Nam. Họ Papilionidae chiếm 37\% tổng số loài của họ ở Việt Nam. Một số loài ở Việt Nam chỉ phân bố ở khu vực Đồng Văn là Byasa hedistus, Papilio elwesi, Sasakia funeblis, S. charonda, Melitaea yuenty. Đây là những loài hiếm hoặc rất hiếm, sống trong các khu rừng, nơi rừng đang ngày càng bị thu hẹp. Chúng đang bị đe dọa, vì vậy, cần có các biện pháp bảo tồn, nhất là bảo tồn sự nguyên vẹn của các khu rừng tự nhiên ở Cao nguyên đá Đông Văn, nơi ở của các loài bướm này.

Tư khóa: Bảo tồn, cao nguyên đá, loài bị đe dọa, loài hiếm, Sách Đỏ Việt Nam.

Ngày nhận bài: 22-4-2014 